УДК 621.396 .67

\title{
ОДНОНАПРАВЛЕННАЯ СВЕРХШИРОКОПОЛОСНАЯ ТОНКОПРОФИЛЬНАЯ ВИБРАТОРНО-ЩЕЛЕВАЯ АНТЕННА
}

\author{
ДУБРОВКА Ф. Ф., ТОЛКАЧЁВ А. В.
}

Нацииональный технический университет Украины

«Киевский политехнический институт»,

Украина, Киев, 03056, пр-т Победь 37

\begin{abstract}
Аннотация. Предложена простая однонаправленная сверхширокополосная вибраторно-щелевая антенна, состоящая из одиночного пластинчатого вибратора, расположенного над экраном и нагруженного на две щели, образованные тремя металлическими пластинами. Представлены результаты численного исследования ее характеристик согласования и излучения методом интегральных уравнений относительно тока и заряда. Оптимизированный вариант антенны имеет тонкий профиль $\left(0,17 \lambda_{\max }\right)$ и в полосе частот $3,2: 1$ обеспечивает уровень КСВН $<2$ при питании фидером 50 Ом, а также практически неизменную форму диаграммы направленности при длинах волн, близких к расстоянию $\lambda / 2$ до экрана, чего невозможно получить для вибраторной антенны над экраном. Показано, что такой эффект достигается благодаря синфазному сложению в переднем полупространстве излучений системы вибратор-щели и экрана.
\end{abstract}

Ключевые слова: вибраторно-щелевая антенна; антенна однонаправленного излучения; сверхширокополосная антенна; тонкопрофильная антенна

\section{ВВЕДЕНИЕ}

В настоящее время, в связи с интенсивным развитием систем электромагнитного зондирования и мониторинга электромагнитной обстановки, существует практический интерес к разработке сверхширокополосных (перекрытие по частоте 2:1 и более) однонаправленных антенн линейной поляризации с предельно низким профилем, особенно для бортовых применений. Плоская логопериодическая антенна [1], расположенная над проводящим экраном, потенциально обладает требуемыми свойствами, однако имеет один недостаток раздвоение диаграммы направленности (ДН), когда электрическое расстояние между экраном и структурой приближается к $0,5 \lambda$, где $\lambda$ - длина волны излучения антенны. Аналогич- ный эффект имеет место и для широкополосных вибраторных антенн.

Появился ряд публикаций [2-7], посвященных новой сверхширокополосной, тонкопрофильной (порядка $\lambda / 8$ на нижнем крае рабочей полосы частот) планарной антенной решетке с линейной поляризацией поля излучения. Она состоит из системы длинных параллельных щелей, возбуждаемых непрерывными ленточными вибраторами [2]. Теоретические исследования такой структуры показали, что она имеет неограниченную полосу, если излучающие щели бесконечно длинные и структура находится в свободном пространстве [4].

Однако наличие экрана, необходимого для практической конструкции, снижает рабочую полосу частот до 4:1 [5], что подтверждается экспериментальными исследованиями $[2,3]$. 